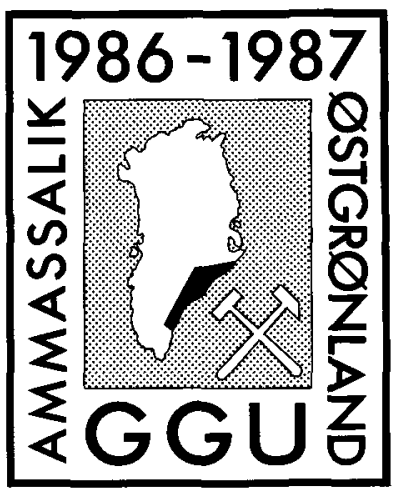

\title{
The geology and structural setting of the Proterozoic Ammassalik Intrusive Complex, East Greenland
}

\author{
C. R. L. Friend and A. P. Nutman
}

\begin{abstract}
The rocks of the Ammassalik area comprise reworked Archaean gneisses and a variety of mainly pelitic to psammitic Proterozoic metasediments. Proterozoic deformation caused thrust intercalation of the rocks and folded them into overturned, southerly directed nappes. Three dioritic centres, collectively named the 'Ammassalik Intrusive Complex' in this paper, were emplaced into a tract occupied by metasediments, causing extensive anatexis. The granitic liquids produced from this resulted in magma mixing with the still liquid diorite; they also formed discrete sheets of augen granite intruding the country rocks. The diorite centres were emplaced as relatively dry bodies, and together with anatexis, they caused the formation of granulite facies assemblages by dehydration reactions in the country rocks. Further away from the contact zone garnet appeared in the surrounding grey gneisses.
\end{abstract}

\section{Introduction}

The central part of the early Proterozoic mobile belt of East Greenland (Bridgwater \& Myers, 1979) is dominated by an WNW-trending zone of orthopyroxenebearing intrusive rocks of mid-Proterozoic age (1886 \pm $2 \mathrm{Ma}$, Hansen \& Kalsbeek, this volume) flanked by heterogeneous garnet gneisses (Wright et al., 1973). Together they form an approximately $30 \mathrm{~km}$ wide belt which runs from the Inland Ice south of Johan Petersen Fjord, east-southeast across the southern part of Angmagssalik $\emptyset$ and on to Kulusuk and the southern part of the islands to the north (fig. 1). The intrusive rocks were first described as enstatite- and hypersthene-bearing by Törnebohm (1886) and later referred to by Wager (1934) as 'basic rocks with charnockitic affinities'. This group of intrusive rocks is re-defined here as the Ammassalik Intrusive Complex (AIC). Studies of these rocks and the adjacent gneiss complex by a team from Birmingham University (Wright et al., 1973) and later by GGU teams (Bridgwater et al., 1978a; Bridgwater \& Myers, 1979) were the starting point for the work reported here.

\section{The gneiss complex}

The oldest unit recognized comprises variably reworked Archaean grey orthogneisses with scattered inclusion trains comprising leucogabbro, gabbro, ultra- mafic rocks, banded amphibolite and rare metasediments. In augen of low Proterozoic deformation, for example central Kitak (fig. 1), the gneiss complex has been affected by high-grade metamorphism and considerable deformation prior to intrusion of closely-spaced, EW-trending, now metamorphosed dykes (mainly tholeiitic dolerites and microgabbros, with some noritic types) of presumed early- to mid-Proterozoic age (e.g. Wright et al., 1973; Bridgwater \& Myers, 1979). Generally the dykes are less than $25 \mathrm{~m}$, but they may be up to $200 \mathrm{~m}$ thick. Discordances are locally preserved, but usually the dykes are strongly deformed into layer-concordant, semi-continuous layers of strings of pods. The mineral assemblages of the dykes observed in the field allow the gneiss complex to be divided into three units (see below).

Only a few sheets of post-dyke gneisses, which are therefore of Proterozoic age, have been found in the region, for example on the northern side of Erqiligârteq and the large island to the west (fig. 1).

North of the AIC a few extremely heterogeneous amphibolite dykes trending NW-SE and up to $50 \mathrm{~m}$ thick have been observed. They consist of jumbled angular blocks of layered melagabbro, gabbro, anorthosite and country gneisses in a hornblende-rich matrix. They are well-preserved, not cut by any gneissic sheets and appear to post-date much if not all of the Proterozoic deformation. 


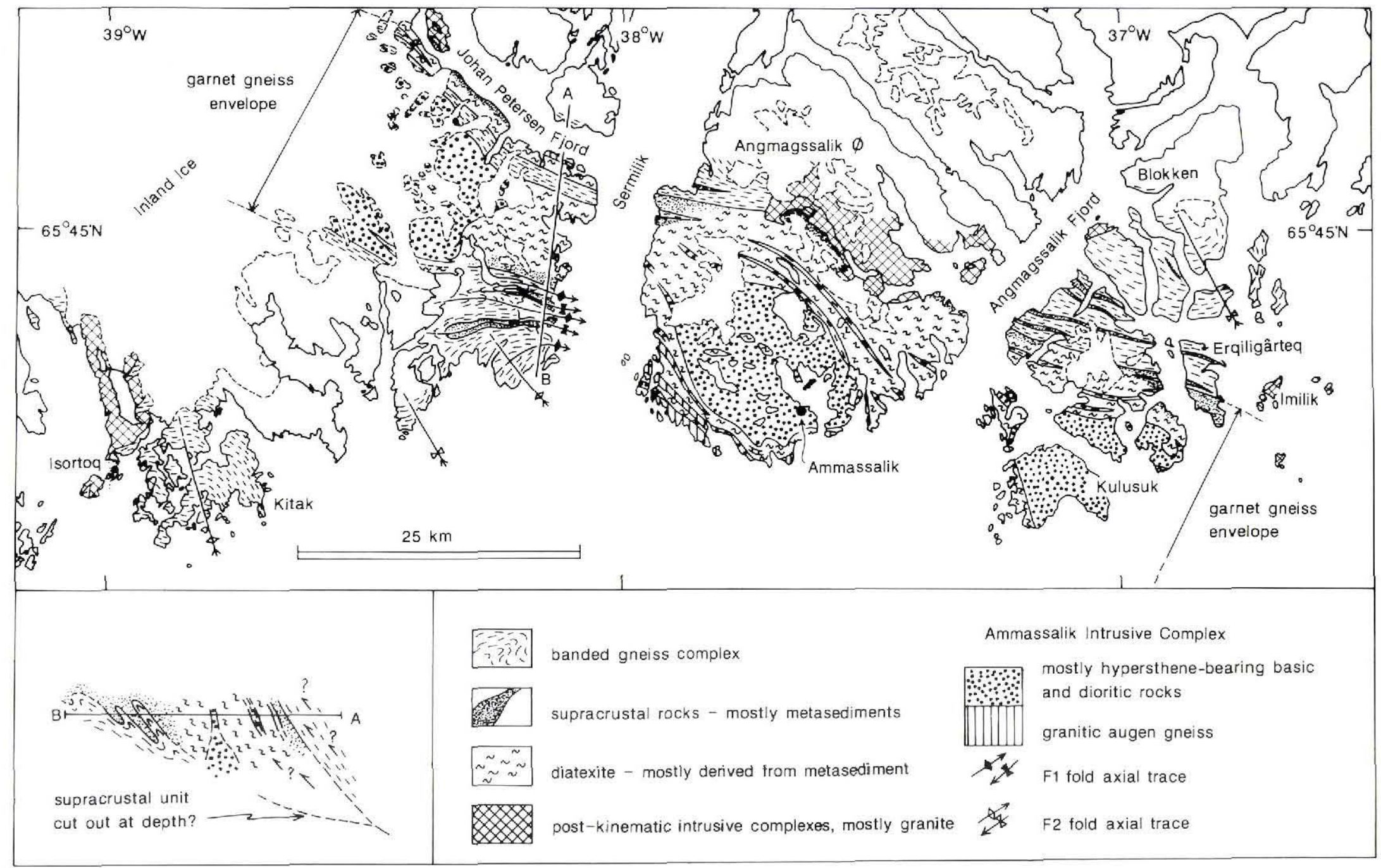

Fig. 1. Geological sketch map of the Ammassalik Intrusive Complex and cross section from Johan Petersen Fjord (A) to Kap Tycho Brahe (B). 
Supracrustal rocks: their structure and relationship with the gneiss complex and the Ammassalik Intrusive Complex

A major structural problem which emerged from the mapping was to explain the intimate association of the grey gneisses and the metasediments. The disposition of these two rock units in the vicinity of Ammassalik had an important role in controlling the effects of the emplacement of the AIC. Some metasedimentary units may be continuous along strike for at least $75 \mathrm{~km}$, with the largest unit several kilometres thick (fig. 1). More usually the units are less than $1 \mathrm{~km}$ thick, the thickness of these units being interpreted as a function of thrusting and folding. Away from the AIC contact zone the dominant supracrustal lithology is a rusty-weathering graphitic schist. Some layers contain sillimanite and in other layers rare kyanite occurs. Garnet quartzite layers up to $1 \mathrm{~m}$ thick, rare carbonate or calc-silicate units up to $5 \mathrm{~m}$ thick and occasional layered amphibolites are also present. No evidence concerning original relationships between the gneisses and the metasediments were observed in the study area. Whilst an unconformity cannot be ruled out (see Chadwick et al., this volume) some of the contacts have to be thrusts (fig. 1). The grey gneisses throughout the Ammassalik area contain postdyke thrusts marked by mylonite zones. The gneisses and supracrustal rocks were intercalated by thrusting and folding together into tight to isoclinal, southerly verging folds $\left(F_{1}\right)$ with axial traces striking approximately WNW-ESE forming the 'layer-cake' of Chadwick et al. (this volume). Analysis of thrusts of similar orientation both to the north (Escher \& Hall, this volume) and the south (Escher et al., this volume) suggests that they all involved southerly directed transport. Contacts between the gneiss complex (with numerous metabasic dykes) and the supracrustal rocks (essentially devoid of dykes) are sharp and simple. Common, thin, semi-continuous units of metasediments within the orthogneisses of the study area are here interpreted either as intercalations bounded by thrust planes, or invaginations formed during the $F_{1}$ isoclinal folding due to rheological differences between the gneisses and the graphitic sediments. This Proterozoic regional deformation was accompanied by low to medium amphibolite facies conditions and little or no evidence of partial melting is seen in the metasedimentary rocks at the present level of exposure. Basic dyke remnants, which are abundant in the orthogneiss complex (see above), are extremely rare in the supracrustal units. The few dykes that do exist, appear to be co-magmatic with the AIC and are thus much younger than the E-W dyke swarm cutting the gneisses.
The supracrustal rocks in the Ammassalik area are correlated with those now established as probably Proterozoic in age (Kalsbeek \& Taylor, this volume). They are suggested to be a cover sequence to the Archaean gneisses which were deformed together (Wright et al., 1973; Chadwick et al., this volume). In the vicinity of the AIC the supracrustal units have been highly modified and now form parts of the garnet gneiss envelope.

Based upon the dyke assemblages recognisable in the field, and the distribution of rock types the Ammassalik area can be divided, from south to north, into three broad units which are at successively higher structural levels. At Kitak (and extending further south to Umîvik, Escher et al., this volume), the structurally lowest grey gneisses contain dykes with garnet amphibolite assemblages and are overlain by a unit dominated by metasediments. The highest structural unit, to the north of the AIC, comprises gneisses which contain dykes with eclogitic assemblages (Nutman \& Friend, this volume).

Following emplacement of the AIC, upright open warps $\left(\mathrm{F}_{2}\right)$ with NNW-trending axial surfaces and wavelengths of up to $10 \mathrm{~km}$ developed (fig. 1). These warps are rare in the AIC and its garnet gneiss envelope; only a few with wavelengths of $1 \mathrm{~km}$ or less are found on the large island north of Kulusuk (fig. 1). The AIC and garnet gneiss envelope seem to have acted as a competent unit during this event, and instead of being folded, were sheared around their margins. The two episodes of folding described here accord generally with the findings of Wright et al. (1973).

\section{The Ammassalik Intrusive Complex (AIC) and its garnet gneiss envelope}

The Ammassalik Intrusive Complex consists of polyphase, late-kinematic, plutonic rocks exposed in three large centres, here informally called the 'Hobbs centre' (west of Sermilik); the 'Ammassalik centre' (on the southern part of Angmagssalik $\emptyset$ ); and the 'Kulusuk centre' (located on Kulusuk and the islands to the north). The rocks involved crystallized from magmas derived from two distinct sources: (1) presumed mantlederived basic rocks, and (2) crustally-derived acid rocks. Because of the intimate relationships between the two different rock types and the evidence of mixing, it has not been possible to completely separate them in the field, so it is considered more appropriate to group the rocks together as one complex. The country rocks into which the AIC was emplaced comprised mainly graphitic semi-pelitic and psammitic metasediments intercalated with slices of the regional grey gneiss complex. These were severely modified by the basic mag- 
mas and now comprise a sequence of garnet-rich anatectic gneisses.

The three centres are slightly ovoid (approximately $20 \mathrm{~km}$ long by $10-15 \mathrm{~km}$ wide) and arranged in an en echelon pattern, centred about $35 \mathrm{~km}$ apart on a WNWESE trend (fig. 1). In the country rocks between the three centres steeply dipping sheets of similar intrusive rocks up to $200 \mathrm{~m}$ thick occur, mostly with trends between NW-SE and N-S. The northern margins of all three centres and the southwestern margin of the Kulusuk centre are near vertical, whilst the southern margins of the Ammassalik and Hobbs centres dip northeast. The outcrops of the three centres may, therefore, represent sections through steep root zones of lobate or sheet-like bodies. Discordances between AIC sheets and rocks of the adjacent garnet gneiss envelope are common and inclusions of tightly folded garnet gneiss lithologies are characteristic of the marginal zone of the centres. This combined with the weak deformation within the centres, clearly establishes the late-kinematic emplacement. Additionally, in many of the thinner AIC sheets and along the marginal zones of the three centres sheets of inhomogeneous granitic material back-vein the dioritic rocks. These can be traced into mobilized diatexitic gneisses and originate from the amalgamation of melt.

The AIC is multiphase and consists predominantly of medium- to coarse-grained diorite and more basic rocks with subordinate amounts of ultramafic material present. Magma mixing involving the granitic phase derived from partial melts of the country rocks produces a variety of inhomogeneous intermediate rocks. Most common AIC lithologies, both acid and basic, may carry orthopyroxene + biotite \pm hornblende with quartz, intermediate plagioclase and, except in the most granitic phases, are normally devoid of alkali feldspar. Clinopyroxene occurs in some of the more basic lithologies, and garnet is found locally where there has been contamination by mobilized country rocks. Throughout the Hobbs centre and locally in the Kulusuk and Ammassalik centres, there has been a widespread but patchy breakdown of orthopyroxene to give aggregates of hornblende \pm biotite, and co-existing orthopyroxene and garnet may be found near country rock inclusions at the margins.

The cores of the centres frequently consist of massive, fairly homogeneous, medium- to coarse-grained dioritic plutonic rocks which generally lack inclusions. In many areas igneous textures and structures are preserved and the sequence of crystallization of phases is very complicated. Towards the margins of the centres the range of rock types increases and individual phases become more heterogeneous with, locally, high concentrations of both AIC and country rock inclusions. Foliation is generally absent in the cores of the centres and becomes stronger towards the margins and in zones of inclusions, which individually are frequently elongate parallel with the structure.

Magma mixing can lead to some spectacular structures due to differences in viscosity and rheology of acid and basic phases. Breccias, balled and flame structures are sometimes developed between phases which were prevented from any thorough mixing. The relationships clearly indicate that the crystallization history of each centre was complicated with phases which were liquid being available at the same time as phases which were behaving as solids. Locally developed in the more mafic phases are nodular and orbicular textures, usually formed from amphibole which may be overgrowing both orthopyroxene and clinopyroxene. These textures are presumed to be essentially igneous in origin.

The garnet gneiss envelope to the AIC consists of diatectic to metatectic paragneisses, and thin units of garnet-bearing ( \pm orthopyroxene) orthogneiss with abundant amphibolite dyke remains. The increase in mobilization of the paragneisses towards the axis of the AIC is demonstrated in the continuous section on the west coast of Sermilik (see section A-B, fig. 1). On the south side of the AIC, progressing north towards the contact of the Hobbs centre, medium-grained, graphitic schists with quartzite layers become coarser grained and start to show lenses and layers of leucosome and progress into metatexites. Leucosome development increases and disruption of the metatexite banding forms inhomogeneous diatexites consisting of coarse-grained granitoid rock with rusty schlieren of restite rich in sillimanite, garnet and biotite. Refractory quartzite layers are transformed into trains of disrupted pods in the granitoid matrix. Of note is the abundance of garnet and sillimanite and the lack of graphite in the diatexites, graphite presumably being consumed in the melting reactions to yield vapour which left the system. Eventually, as the proportion of melt increases sillimanite also disappears. Along the axis of the AIC, between the three centres, the diatexite is locally orthopyroxene bearing and contains segregations of more homogeneous granite. Close to the margin of the AIC, particularly along the southern margin of the Ammassalik centre, sheets of garnetiferous, alkali-feldspar-phyric augen granite, which locally contains orthopyroxene, up to $1 \mathrm{~km}$ thick occur cutting the garnet gneisses. These granites are both in situ melts from the metasedimentary rocks and are intrusive sheets into them. They are interpreted as demonstrating the early stages of melt accumulation and it is magma produced from this anatectic event that mixes with the dioritic magmas. Thin 
dioritic dykes and sheets, correlated with the AIC, cut the garnet gneisses, but were disrupted into pods during the formation of the diatexites. These commonly have amphibolite facies cores, but granulite facies, orthopyroxene + plagioclase-bearing margins. This dehydration of amphibole is interpreted to be caused by the local scavenging of water by the host diatexite which was water-undersaturated. Units of orthogneisses in the envelope develop garnet and, close to AIC centres, may attain granulite facies assemblages by dehydration reactions, but show only very limited partial melting or mobilization.

In conclusion the field relations and mineral assemblages show that the AIC consists of polyphase intrusions, whose melts were fairly dry and crystallized directly into orthopyroxene-bearing rocks. The progressive mobilization of the paragneiss country rocks towards the axis of the complex is interpreted as a contact metamorphic aureole. The general lack of coexisting garnet and orthopyroxene in basic rocks and the occurrence of sillimanite as one of the restite phases in the diatexites, suggest that the complex was emplaced at mid-crustal levels. The AIC is not cut by the Proterozoic dykes, and even its marginal parts are only weakly deformed. Therefore it is interpreted as a late-kinematic intrusion (cf. Bridgwater \& Myers, 1979). There is no evidence to support the hypothesis that these rocks represent exotic, deep crustal rocks thrust into their current position during the Proterozoic as proposed by Wright et al. (1973).

\section{Post-kinematic intrusive complexes}

To the north of the AIC three post-kinematic complexes, consisting of predominantly granite with subordinate diorite and gabbro, were emplaced on an approximately parallel trend and roughly opposite each of the AIC centres. These younger complexes have brittle intrusive relations and were interpreted to have been emplaced at high crustal levels (Wager, 1934). They give ages of $c .1580 \mathrm{Ma}$ (Pedersen \& Bridgwater, 1979; Taylor $e$ al., 1984), and have been described by Wright et al. (1973), Bridgwater \& Myers (1979) and Tarney \& Saunders (1979). Evidence for a thermal perturbation associated with these complexes is found in metasedimentary enclaves occurring close to the contact which contain andalusite partially pseudomorphing kyanite. Otherwise no contact metamorphic effects were observed.

\section{Late dolerite dykes}

All rock groups of the region are cut by sub-vertical dolerite and microgabbroic dykes which commonly have a trend of $c .030^{\circ}$, or less commonly c. $070^{\circ}$. Occasional $\mathrm{N}-\mathrm{S}$ trending feldspar-phyric basic dykes are cut by the $030^{\circ}$ and $070^{\circ}$ dykes. Some or all of these dykes are Tertiary in age (Wright, 1971). They form less than $1 \%$ of the outcrop, and they decrease in abundance to the west, away from the coast. Some of the larger dykes have igneous layering or felsic segregations and late felsic veins which transgress layering in the dykes. 